\title{
PROCESS MODELING OF MAKING THE OUTPUT OF PRODUCTS
}

\section{Bezus P. I.}

\section{INTRODUCTION}

The imperfection of the structural restructuring of the Ukrainian economy, the unsatisfactory investment climate and the poor level of market relations have led to the fact that today the gross domestic product (GDP) has not reached even $60 \%$ of the 1990 level of GDP ${ }^{1}$. This situation is complicated by the fact that specific microeconomic units (producers of gross domestic product) are in a state of limited resources and, in turn, limits their ability to increase production. Therefore, providing limited resources, special attention should be paid to methods of increasing productivity output by business entities without attracting investments by identifying and optimizing the use of reserves for each production factor.

Determining the dynamics of changes in each studied production factor based on the manufacturing simulation makes it possible to timely identify reserves and on this basis to determine a way to increase production efficiency and achieve the desired output of products with optimal costs.

\section{Forecasting production reserves}

The identification of production reserves is carried out both by enterprise units and by production factors (material resources, labor, energy, financial resources, fixed assets).

If the need for the costs of the studied factors and their proportions for the production of a unit of production are unchanged, it is possible to forecast production reserves for each factor.

To simulate the behavior of the production system in time, it is necessary to construct a mathematical forecast function $f(t)^{2,3}$. If we

\footnotetext{
${ }^{1}$ Статистичний щорічник України за 2016 рік. Державна служба статистики України. Київ : ТОВ «Август Трейд», 2017. 552 с.

2 Безус П.І. Моделювання нарощування обсягів виробництва. Економіка та підприємниитво : Збірник наукових праць. 2007. Вип. 18. С. 307-312.
} 
analyze the volume of production, then in a certain time interval $t$ it will change in accordance with the forecast function:

$$
Z_{p}^{t}=f_{p}(t), p=\overline{1, m ;} t=\overline{1, T},
$$

where $Z_{p}^{t}$ - the gross output of type $p$ in the time interval $t$.

To ensure the necessary volume of production, it is necessary to use a certain amount of each type of resource in certain proportions. In this regard, the amount of the resource should not be less than the value determined at a fixed point in time corresponding to its share in units of production (coefficient of expenditures of a certain resource).

To ensure the predicted volume of this type of product $(p)$ for the considered period of time $t$ (f.1), the required amount of the resource is calculated by the formula:

$$
\overline{Y_{r p}^{t}}=\nu_{r p} \cdot Z_{p}^{t},
$$

where $v_{r p}$ - resource consumption rate $r(r=\overline{1, g})$ per unit of product type $p, p=\overline{1, m}$;

Based on the predictive function to ensure the production process, you can determine the amount of this resource for the manufacture of products of type $p$ for each time interval:

$$
Y_{r p}^{t}=f_{r}(t) ; r=\overline{1, g} ; \quad p=\overline{1, m} ; \quad t=\overline{1, T}
$$

When comparing the required amount of a resource (f.2) with the forecasted amount of the same resource (f.3), it is possible to determine its reserves at each time interval in the future:

$$
\Delta Y_{r p}^{t}=Y_{r p}^{t}-\overline{Y_{r p}^{t}}
$$

Given that under the influence of the external environment, the proportions defined between resources cannot remain constant, their changes must be taken into account when identifying production reserves in the future. Based on changes in the respective proportions in the past, the prognosis of the proportions of the amount of the attracted resource for production is carried out according to the following formula:

\footnotetext{
${ }^{3}$ Скурихин В.И., Шифрин В.Б., Дубовский В.В. Математическое моделирование. Київ : Техніка,
} 1983. $270 \mathrm{c}$. 


$$
\boldsymbol{V}_{r p}^{t}=f^{r p}(t), t=\overline{1, T ;} \quad p=\overline{1, m} ; \quad r=\overline{1, g}
$$

where $v_{r p}^{t}$ - the predicted proportion of the amount of resource $r$ to the number of products of the $p$ - type in a period of time $t ; t=\overline{1, T}$.

To ensure the volume of production $\left(Z_{p}^{t}\right)$, which is predicted for a certain time interval $t$ and taking into account the forecast of the proportion of the amount of resource to production $\left(v_{r p}^{t}\right)$, it is necessary to use the following amount of resource $r$, which is:

$$
\tilde{Y}_{r p}^{t}=v_{r p}^{t} \cdot Z_{p}^{t},
$$

where $v_{r p}^{t}, Z_{p}^{t}$ - are determined by the corresponding forecasting functions according to formulas (5) and (1).

Then the reserves of this resource for each future point of time:

$$
\Delta \tilde{Y}_{r p}^{t}=Y_{r p}^{t}-\tilde{Y}_{r p}^{t} .
$$

In addition to forecasting reserves for production resources, it is necessary to apply forecasting of production reserves by its divisions for the intensive development of an enterprise. The forecasting of reserves by enterprise units is carried out similarly with the forecasting of reserves for each type of resource involved in production. The need of process simulation for individual divisions of the enterprise, due to the variety of processes that take place in different divisions, the variety of products that they produce, and the different functions they perform, while forecasting the total volume of production does not provide the opportunity to fully analyze the activities of the enterprise.

To determine the production reserves for a certain period, it is necessary to correlate the actual value of the sought indicator with the potential (the maximum possible value that it could achieve under the most favorable conditions). So, the production reserves of any enterprise for a certain period can be determined by the formula:

$$
\Delta \mathrm{V}=\mathrm{P}-\mathrm{V},
$$

where $P$ - potential capacity of the enterprise (potential);

$V$ - actual production volumes for the study period. 
Potential production capacity is determined by the formula ${ }^{4}$ :

$$
P=P_{0}+\frac{1}{T} \sum_{t=1}^{T} \Delta P_{t}(T-t),
$$

where $P_{0}$ - standard production capacity;

$t$-appropriate planning period interval, $t=\overline{1, T}$;

$\Delta P_{t}$ - change in the capacity (potential) of the enterprise in the time $t$.

Given that the production potential of an enterprise depends on many factors, each of which has its own reserve of power, each factor has an impact on production capacity and is an integral part of the production process. It has a throughput capacity, ensures the implementation of production capacity at the level of the calculated potential value. If for the production potential we take the maximum possible production capacity taking into account all factors, then the reserve calculated by the formula (8) can be called full. To realize the full reserve, it is not necessary to increase the capacity for any factors, but only create favorable conditions for the use of the existing capacity factors. When determining the reserves of any factors, as a rule, the normative method for calculating the capacities of the studied factors is used, when using which there are significant inaccuracies, as a result of which the average value of the power is underestimated by $20 \%{ }^{5,6}$. The application of the proposed method for calculating will reveal additional reserves of the analyzed factors.

Reserves for increasing production over the study period can be analyzed by component intervals. For this, it is necessary to consider changes in a certain indicator for the study period, consisting of a specified number of time intervals $(T)$. For the analysis of reserves, the symbols is introduced where: $P_{t}$ - the production potential of the enterprise for the time interval $t$, and $V_{t}$-is the actual volume of production of the enterprise for the interval $t$. Thus, the analysis of the production reserve $\Delta V_{t}$ by the components of the time intervals makes it possible to identify reserves for each time interval:

$$
\Delta \mathrm{V}_{\mathrm{t}}=\mathrm{P}_{\mathrm{t}}-\mathrm{V}_{\mathrm{t}}, \mathrm{t}=\overline{1, T}
$$

\footnotetext{
${ }^{4}$ Безус П.І. Моделювання процесу економічного розвитку виробничого підприємства : автореф. дис. на здобуття наук. ступеня канд. екон. наук : спец. 08.00.11 «Математичні методи, моделі та інформаційні технології в економіці». Київ, 19 с.

${ }_{5}^{5}$ Крамаренко В.І. Управління ресурсами підприємства. Київ : ЦНЛ, 2004. 288 с.

6 Антоненко Г.Я., Клименюк Н.Н., Калишук Д.А. Производственный потенциал предприятий сборного железобетона. Київ : Вища школа, 1982. 132 с.
} 
After determining the reserves for each time interval for their practical use, it is necessary to sort the values of the reserves in descending order, identify the causes of their underutilization, develop and implement measures to eliminate them. The calculation of the total production reserves represented by equations (8), (10) is the simplest, but their practical use is difficult due to insufficient specificity. In this regard, practical interest appears in the analysis of identified production reserves for each factor separately. Factors include both production resources and production units.

To analyze production reserves for each individual factor, the following symbols is introduced:

$i$ - factor number; $i=\overline{1, n}$;

$n$ - number of considered factors;

$P_{i}, P_{i t}$ - the production potential of factor $i$ for the entire studied period and, accordingly, for the compound time interval $t$;

$V_{i}, V_{i t}$ - actual parameters (volumes) of factor $i$ for the entire study period and, accordingly, for the intervals of which it consists $t$.

The subsequent analysis of production reserves for the study period and each component time interval makes it possible to determine the reserves for individual time intervals for each of the analyzed factors.

The absolute reserves of factor $i$ for the studied period of time are:

$$
\Delta \mathrm{V}_{\mathrm{i}}=\mathrm{P}_{\mathrm{i}}-\mathrm{V}_{\mathrm{i},}, \mathrm{i}=\overline{1, n} .
$$

The relative reserves of factors can be determined by the following formula:

$$
\Delta \mathrm{V}_{\mathrm{i}}=\frac{P_{i}-V_{i}}{P_{i}}, \mathrm{i}=\overline{1, n},
$$

An analysis of an enterprise's reserves by production factors in some cases may reveal additional reserves. This is possible when favorable conditions have led to the fact that the actual value of the indicator of the studied factor exceeded the previously fixed value of the indicator of this factor. Thus, the total reserve will be:

$$
\sum_{i=1}^{n} \Delta V_{i}=\sum_{i \in\left\{i, n \in V_{i}<V_{i}<P_{i}\right.}\left(P_{i}-V_{i}\right),
$$


In this case, the total reserve exceeds the value of the reserve of the enterprise, i.e. $\sum_{i=1}^{n} \Delta V_{i}>\Delta V$.

Based on the analysis of the company's reserves by production factors, it becomes possible to identify additional reserves of this production as a whole:

$$
\Delta V_{\partial}=\sum_{i=1}^{n} \Delta V_{i}-\Delta V
$$

If a production unit is considered as a factor, then, by analogy, an analysis of the enterprise's reserves by units may reveal additional production reserves when the actual output exceeded the previously recorded value of production potential in at least one of the enterprise's units.

Compared with the analysis of reserves for production units, the analysis of the enterprise's reserves for production resources, such as labor, raw materials, material resources, fixed assets, energy resources, is the most difficult. Production reserves for each of certain factors are partial, since only their joint use will lead to an increase in production. The complexity of the analysis lies in the fact that to determine the reserves for these production factors, it is necessary to obtain information on the actual state of use of each factor for a certain period of time and their maximum throughput (potential). To compare these two values for each of the factors, they must be expressed as the number of units of products that can be made from the existing volume of this factor. The value of the indicator of the actual use of the factor of production is determined on the basis of information on the volumes of manufactured products, and the calculation of the potential or maximum possibility of this factor is carried out according to the normative method.

In almost every enterprise there are significant imbalances in the use of the main factors - resources, leading to a significant decrease in the productivity of enterprises and a decrease in their economic indicators. Numerous factors affecting the production of finished products lead to uneven development of production units of the enterprise. On this basis, the company has bottlenecks that do not allow to use the potentials of other production units to a sufficient extent. A certain increase in production under such conditions is not provided, and therefore the economic efficiency of the enterprise is reduced. Thus, the identification of those 
divisions and factors whose carrying capacities in the future may hamper the development of the entire enterprise, the determination of the period of occurrence of imbalances and their values will make it possible to take timely measures to increase the proportionality of the development of production divisions and production factors.

The most important among the production factors can be identified such integrated groups of resources as material, labor, energy resources. If the throughput of at least one of them is lower than the production capabilities of the enterprise unit, the volume of output will be constrained by the throughput of this component.

It is quite difficult to establish an unambiguous correspondence of production capabilities for the listed components of the production process in production due to its dynamic nature associated with constant changes in the number of employees, in the number and nomenclature of products, in the amount of raw materials involved, etc. every fixed point in time.

At the first stage, it is necessary to consider the ratio at the moment in time of the production capabilities of labor, material, energy resources and equipment. The established proportions of the production capabilities of these factors can be presented in the form of a diagram (Fig. 1), where, respectively, $M_{1}, M_{2}, M_{3}, M_{4}$ - are the production capabilities of labor, material, energy resources and equipment; $\Delta M$ - the value of increasing the production capabilities of factors. The production capacity of the enterprise, in accordance with the regulatory method for its determination, is always equal to the production capacity of the equipment: $M=M_{4}$. In fact, the production capacity of the enterprise does not correspond to this equation. This is due to the fact that the volume of production even with the assumption of the full use of the capabilities of each of the factors is defined as:

$$
V=\min \left\{M_{i}, i=\overline{1, n}\right\},
$$

where $i$ - process factor number.

Analyzing the ratio of production capabilities of factors, which is reflected in the diagram, it can be concluded that to increase production to the level of installed production capacity, it is enough to take measures to increase the production capabilities of labor and material resources, where increase of the production capabilities of material resources will be $\Delta M_{2}$, and increase of production capabilities labor resources will be $\Delta M_{1}$. Thus, 
this will ensure an increase in output by a significant amount equal to the largest of the two named values of the build-up, that is, $\Delta M^{\prime}=\Delta M_{2}$. With the possible implementation of the necessary measures, it is envisaged to increase production volumes to the level of production capacity $M$.
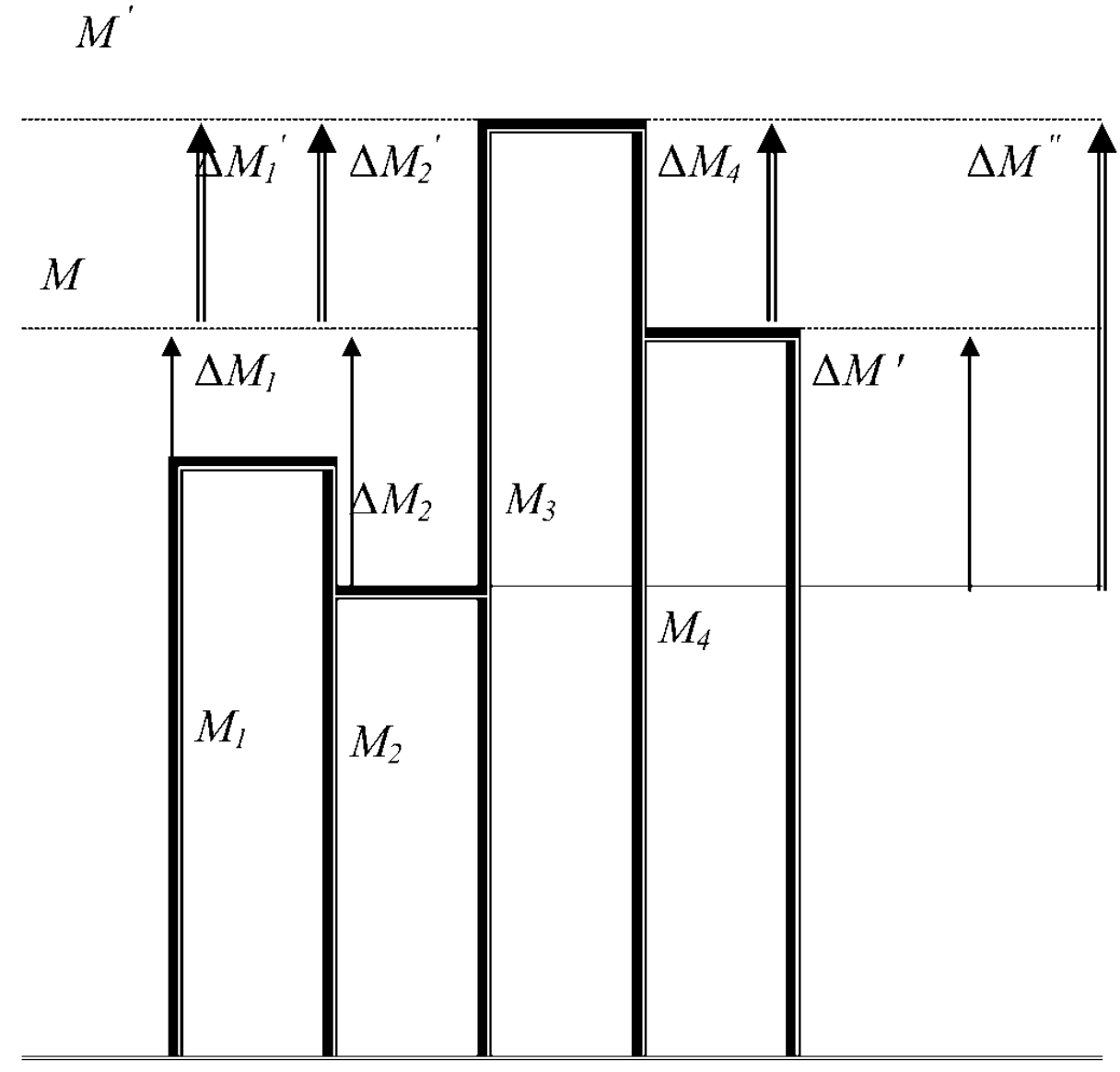

\section{Fig. 1. The diagram of the ratio of production capabilities of factors}

But it is possible to further increase production volumes due to the identified reserves of all factors (fig. 1). To further increase production to the level of production capacity $M^{\prime}$ it is assumed that measures should be taken to increase the production capabilities of labor, material resources and equipment. Due to the fact that at the first stage these values reached a level that can provide the same volume of output (level $M$ ), their increase at this (second) stage will be $\Delta M_{4}$, which will be equal to the value of $\Delta M_{2}{ }^{\prime}$ and also to $\Delta M_{1}^{\prime}\left(\Delta M_{4}=\Delta M_{1}^{\prime}=\Delta M_{2}^{\prime}\right)$. Thus, having achieved the implementation of all the above measures, we will ensure an increase in 
output by an amount equal to the sum of two stackable quantities in the first and second stages

$$
\Delta \mathrm{M}^{\prime \prime}=\Delta \mathrm{M}^{\prime}+\Delta \mathrm{M}_{4}
$$

In general, provided that all stages of production increase are fully implemented, it is possible to provide for an increase in production volumes to the level of production capacity $M^{\prime}$.

Each production process can only be carried out in accordance with the proportions for the use of various types of resources defined for a given production. Therefore, the volume of production is limited to that resource, the production capacity of which is the smallest. If the production capabilities for each of the factors are used in full, the production volumes of the enterprise $(V)$ are determined by the production factor that has the minimum throughput. This value is called the production potential of the enterprise $^{7,8}$. The production potential of the enterprise is associated with the actual production of such a condition:

$$
V \leq P=\min \left\{P_{i}, i=\overline{1, n}\right\},
$$

where $P$ - production potential of the enterprise;

$P_{i}$ - production potential of the factor $i$;

$n$-number of factors i.e. components of the production process.

The cases considered above that made it possible to assess the capabilities of the enterprise by its production capacity differ from the methods for assessing the capabilities of the enterprise by production potential.

When analyzing the production activity of an enterprise at a certain point in time, its capabilities in terms of labor, material, energy resources and equipment are unequal and are equal to $P_{1}, P_{2}, P_{3}, P_{4}$, the values of which are shown in the diagram (fig. 2).

As can be seen from the diagram, the production potential of the enterprise is equal to the lowest value of the potential of one of the factors $\left(P=P_{1}\right)$.

Based on the accepted conditions, the value of production potential characterizes the value of the productivity of the enterprise as a whole and coincides with it. The volume of output depends on the production potential of

\footnotetext{
7 Антоненко Г.Я., Клименюк Н.Н., Калишук Д.А. Производственный потенциал предприятий сборного железобетона. Київ : Вища школа, 1982. 132 с.

${ }^{8}$ Гавва В.Н. Потенціал підприємства: формування та оцінювання. Київ : ЦНЛ, 2004. 224 с.
} 
the enterprise and therefore, to increase production, it is necessary to increase production capacity. To build capacity, let's say from level $P$ to level $P^{\prime}$ (aig. 2), it is necessary to increase the production potential of labor, material resources and equipment by appropriate values, which is $\Delta P_{1}, \Delta P_{2} \mathrm{i} \Delta P_{4}$.

The production potential for various types of resources at each enterprise and in each individual time interval can vary. The proportions of the production potentials of these resources also change, and in connection with this, the production potential of the entire enterprise changes.

The analyzed situation is fixed in time and does not reflect the influence of constantly acting random factors arising in the course of production processes. In real conditions, the task of increasing productivity is different in that its performance indicators cannot be indicated by a single number due to the constant influence of random factors. Thus, a factor with a minimum value of performance is a constraining factor at a given time.

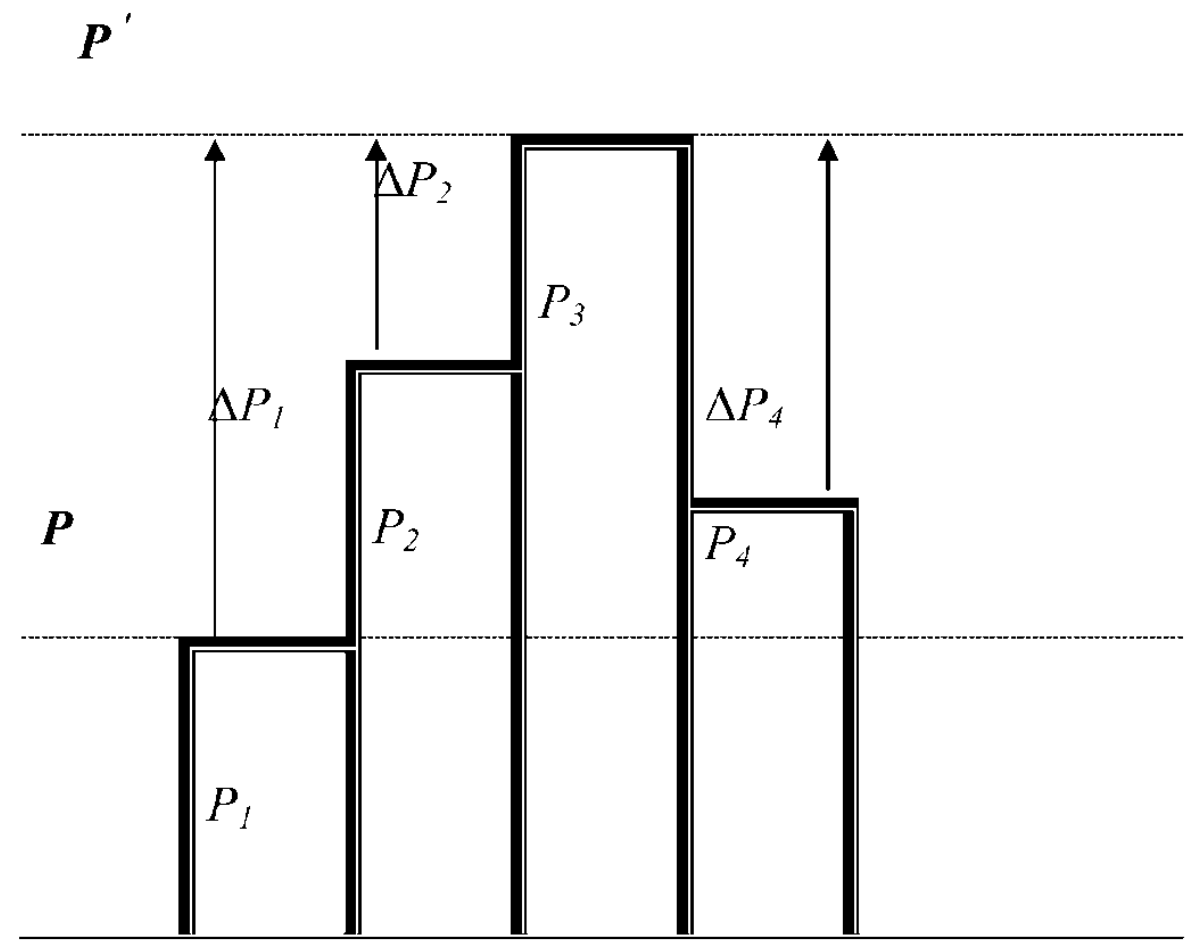

Fig. 2. The diagram of the ratio of production potentials of the studied factors

In addition to the influence of all existing factors on the production volume of the enterprise, for the most detailed analysis of production, we can study the dynamics of changes in the productivity indicator for each 
individual production factor. A detailed study of the dynamics of changes in the performance indicator for each factor of production over a long period makes it possible to establish the corresponding limits of changes in this indicator. The volume and nature of changes in productivity for each factor of production over time are determined by the relevant laws. After establishing the maximum and minimum boundaries of the indicator of production capabilities of the studied factor, you can set the average value of this indicator for a certain period of time using the following formula:

$$
\bar{V}=\frac{\sum_{t=1}^{T} V_{t}}{T},
$$

where $V_{t}$ - indicator of production capabilities of the factor, which is analyzed in the time interval $t$;

$t$-number of the investigated moment of time, $t=\overline{1, T}$.

In the process of research, the nature of the corresponding changes in productivity indicators for each production factor over time is determined and the boundaries of their deviations are compared and their average values are determined by the formula (17), (fig. 3).

$M$ - enterprise production capacity;

$\overline{V_{1}}, \overline{V_{2}}, \overline{V_{3}}, \overline{V_{4}}$ - average production capabilities of factors.

If during the analysis, when comparing the average values of the indicators of production capabilities of factors, a factor appears that has a significantly lower indicator among them, then a further solution to the problem of increasing production volumes of the enterprise is directed to taking measures to increase average production capabilities for this factor of production.

However, there are cases when the average values of production capabilities of various factors are close to each other. Let us suppose that when analyzing the production activity of an enterprise over a certain period of time, the average values of production capabilities of various factors are equal. Then, in accordance with the above, the increase in the average value of one of the factors will not lead to an increase in the volume of production. Because, as noted, to increase the volume of production of the enterprise, in this case, can only lead to an increase in production capabilities for all factors. But taking into account the peculiarities of changes in production factors and their interaction, we can conclude that even with equal average 
values of indicators of production capabilities of the studied factors, an increase in any of them will lead to an increase in the productivity of the entire enterprise.

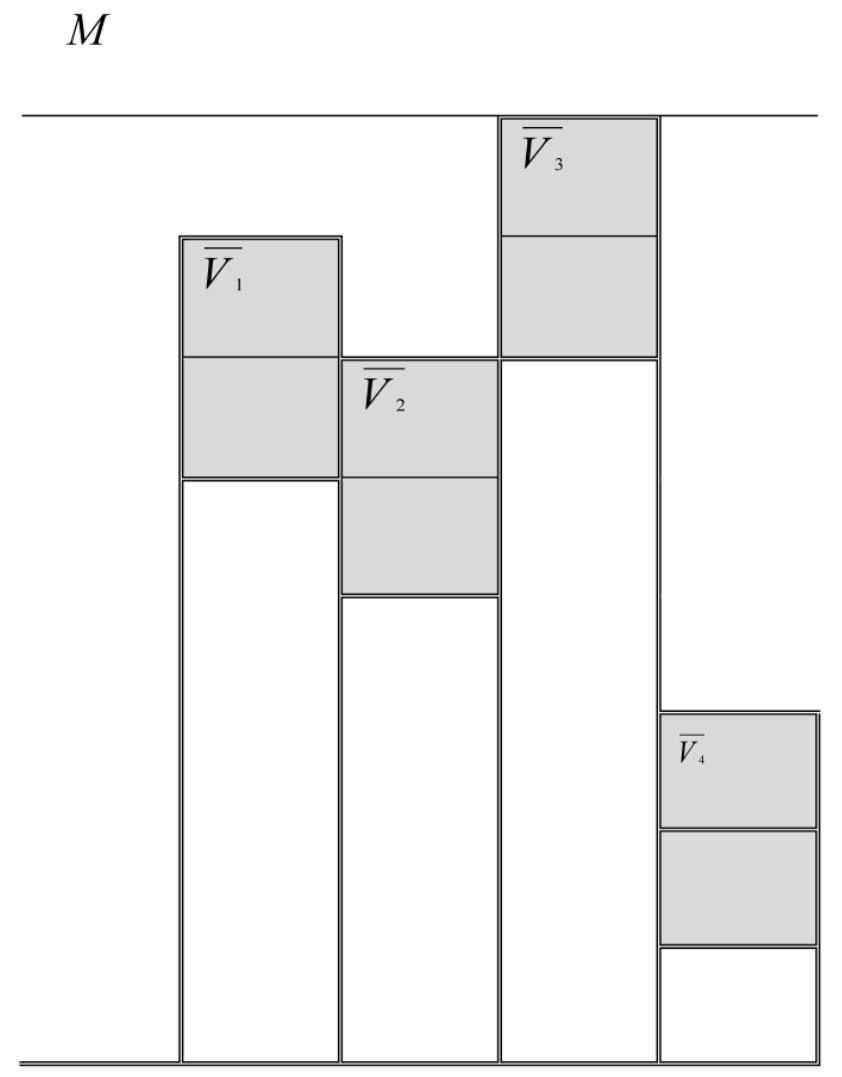

\section{Fig. 3. The nature and boundaries of changes in the production capabilities of factors of production}

In general, the dependence of increasing the production volume of any enterprise on increasing the production capabilities of a single factor, the average value of which is the smallest among the factors, depends on the conditions prevailing in this enterprise. The dependence of increasing the production volume of the enterprise on one factor is carried out according to the dependence characteristic of the enterprise (fig. 4). The initial increase in the enterprise's production by increasing the average indicator of the studied factor can be carried out according to a linear relationship, but its further increase begins to be reproduced in accordance with the dependence described by the nonlinear function. 
Analyzing the graph, it can be noted that an increase in enterprise production due to an increase in the average indicator of the studied factor in the section from $V_{i 0}$ to $V_{i l}$ is displayed by a linear relationship.

This happens because this dependence at a given time reflects such production conditions when other factors do not have a negative effect and an increase in production volumes, that is, the average value of the production capabilities of the concidering factor is much less than the productivity of other factors of this production.

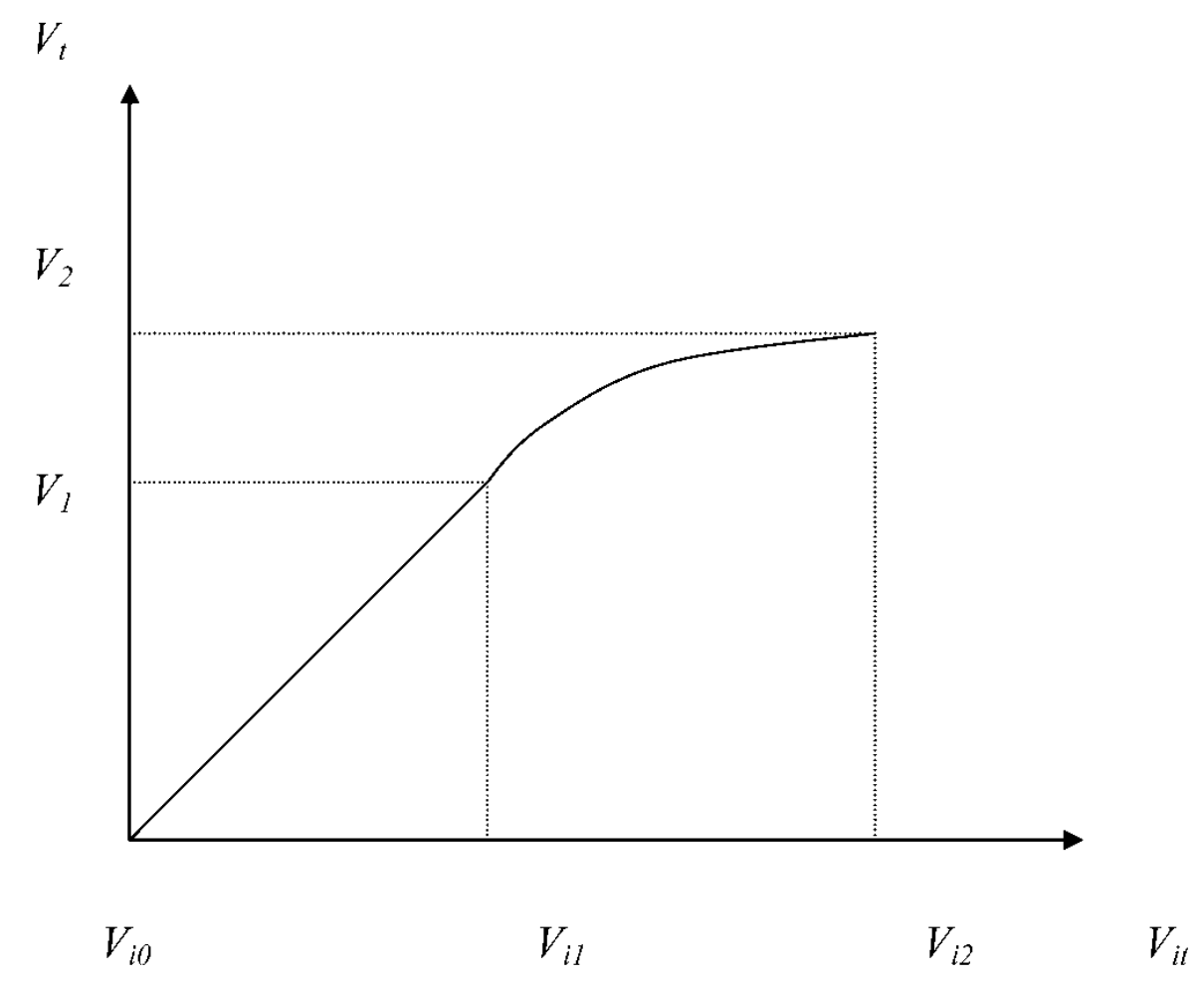

Fig. 4. The dependence of the increase in the volume of production of the enterprise $\left(V_{t}\right)$ on the increase in production capabilities of the factor $i\left(V_{i t}\right)$.

This situation will be observed until the upper boundary of the production capabilities of this component reaches the lower boundary of the production capabilities of any of the other factors of production and, therefore, from this stage, at some points in time, the constraining factor will be the production factor that has the smallest of production capabilities in a given time interval. 
Upon further analysis of the graph, it can be noted that in the area of increasing the indicator of production capabilities of factor $i$ from $V_{i 1}$ to $V_{i 2}$, changes in production volumes of an enterprise from increasing volumes of only this component begin to be described by a nonlinear dependence arising between them. And this happens because a further increase in the production capabilities of this factor can no longer lead to a proportional increase in the productivity of the enterprise as a whole due to the influence of other factors of production, that is, with their deterrent effect.

\section{The model of optimal production growth}

The considered methods of increasing production volumes can influence the increase in production efficiency. But in order to develop the best option for increasing production volumes, to determine the groups of factors affecting changes in production volumes of an enterprise, it is necessary to carry out a correlation and regression analysis. According to its results, there is a need to clarify the magnitude of the influence of these factors on production volumes since the above analysis establishes only a general view of the dependence of factors.

Due to the complexity that may arise when constructing a function that should reflect the dependence of changes in production volumes on increasing volumes of each of the factors, taking into account their mutual influence, it becomes necessary to apply process modeling to determine these dependencies.

To determine the parameters of changes in each of the factors, it is necessary to use data that characterize the dynamics of production and provide an opportunity to obtain the existing regularity of changes in these factors. Based on these data, for constructing models, it is necessary to apply the values behind the studied dependencies using time series. Before building models of the dependences of the volume of production on each of certain factors, it is necessary to find out the mechanism of influence of each factor on production ${ }^{9}$. To identify at each analyzed point in time the potential value of output by the studied factor, it is necessary, taking into account the actual value of the volume of output, to determine the amount of underutilization of this factor through the deterrent effect of other factors.

\footnotetext{
${ }^{9}$ Безус А.М., Безус П.І. Управління розвитком підприємства: моделі та методи : монографія. Київ : ВПЦ АМУ, 2008. 152 c.
} 
The size of the underutilization of the studied factor due to the impossibility of implementing other factors at a given time is the value of exactly that additional production volume that could be produced at this enterprise in the absence of restrictions on other production factors.

To determine the volume of underutilization of the studied factor over any period of time (for example, a 24-hour period), it is necessary to take into account the total amount of all downtime due to a lack of other resources. Thus, the existence of data on actual volumes of production and on volumes of products that are not manufactured due to limited opportunities for other components of production, provide an opportunity to determine the potential output with the full implementation of the studied factor:

$$
V_{i t}=V_{t}+\Delta V_{i t}, \quad i=\overline{1, n} ; t=\overline{1, T},
$$

where $V_{t}$ - indicator of the volume of production of the enterprise in the time interval $t$;

$V_{i t}$ - potential production volume of the enterprise, which can be obtained in the time interval $t$ with the full realization of the factor $i$;

$\Delta V_{i t}$ - the size of the unfinished volume of production in the time interval $t$ due to limited capabilities in other components of production except for the factor $i$;

$i$ - considering factor number, $i=\overline{1, n}$;

$t$ - number of the investigated moment of time, $t=\overline{1, T}$.

So, having determined the volume of output shortage of products that could be manufactured under the condition that the investigated factor is fully realized, it becomes possible to determine the potential output for a given period of time. Based on the obtained data, it becomes possible to determine the type of predictive function that will allow you to predict the necessary trend of a number of dynamics:

$$
V_{i t}=f_{i}(t), i=\overline{1, n} ; \quad t=\overline{1, T},
$$

Thus, the obtained functions for each production factor make it possible to study the effect of each of them on the production process and to establish the dependence of changes in production volumes on the increase in the volumes of the studied factors. 
To establish the dependence of changes in production volumes on the degree of increase in the magnitude of the investigated factor, it is necessary, based on actual data, to determine the potential production volumes per day for each of the studied factors. Then, based on these data, determine the production volumes of the enterprise (unit) per day, based on the fact that $V_{t}=\min _{i}\left\{V_{i t}\right\}, t=\overline{1, T}$. The annual production volume consists of the daily values of this indicator, i.e. $V=\sum_{t=1}^{T} V_{t}$.

Based on the size to which this factor will increase, a certain interval of its changes, or step, is taken. The number of intervals is determined depending on the characteristics of the factor, that is, if the growth of the factor leads to a nonlinear dependence, it is advisable to take about ten intervals of gradual changes in the values of the studied factor, if this dependence approaches linear - the number of intervals can be reduced.

Having determined the volume of the buildup of the studied factor and the number of intervals, the value of the interval equal to $l_{m}, m=\overline{1, L}$ is taken.

After accepting the value of the interval, that is, determining the value by which you can increase the value of this factor, for example $\left(l_{1}\right)$, you need to adjust the initial function by this factor, and for this you need to increase the free term of the function by the value $l_{1} \bar{V}_{i}$, where $\bar{V}_{i}$ is the average value of the production capabilities of the $i$-factor. In this regard, replace the initial function for this factor with the adjusted one and then, on the basis of this, determine new values of the enterprise (unit) production volumes per day and for the whole year.

After the calculations performed in two stages, it is possible to obtain the first point of dependence of the increase in production volume on the factor increase, which is determined on the one hand by the parameter of the factor increase, that is, $l_{l}$, and on the other hand, the increase in annual production volume $\left(\Delta V_{l}\right)$, which is calculated by determining the difference between the last adjusted value of the volume of production of the enterprise and its initial value.

Thus, we obtained the first dependence point with the following coordinates $\left(l_{l} ; \Delta V_{l}\right)$.

To obtain other dependency points under construction, it is necessary to repeat the chain of the described calculations, starting with a twofold increase in the value of the studied factor, i.e., up to $l_{2}=2 l_{1}$. 
So, after calculating all the necessary parameters, using the developed method, you can get a set of points $\left(l_{m} ; \Delta V_{m}\right)$, that form the desired dependence of increasing the volume of production on increasing the volume of the studied production factor ${ }^{10}$.

In the same way, after appropriate calculations for each of the factors selected during the analysis of production, the dependences of increasing production on the changes in each of these factors are obtained. For the task of optimally increasing the production volumes of an enterprise by identifying and using existing production reserves, it is necessary, first of all, using correlation and regression to determine the group of factors that are most influential on the production process and to build an economicmathematical model of the optimal increase in production volumes.

To realize an increase in production volumes by the indicated value, it is necessary to influence the group of the most influential factors determined by preliminary analysis in order to increase their production capabilities or volume. But you need to take into account the fact that each of the factors has a certain area of its growth. Introducing into the model the value of the limiting value of growth, set restrictions on each of the factors.

Let us suppose that in the course of the correlation and regression analysis, the group of the most influential results of the production of factors is determined consisting of the number of industrial production personnel $(K)$, total volumes of raw materials received $(L)$, the active part of fixed assets $(M)$.

To determine the limitations, the above factors are introduced into the mathematical model of the problem with the indication of those quantities that are limiting for each of the factors in accordance with the capabilities of the enterprise. Thus, the following values acquire a restriction for each of the factors: $0 \leq \Delta K \leq a ; 0 \leq \Delta L \leq b ; 0 \leq \Delta M \leq c$, where $a, b, c$ - limiting values of the buildup of each factor.

But specifying the areas of change of factors is not enough to fully formulate the limitations of the model of this problem. It is also necessary to determine the effect of the growth of each of the factors on the change in the indicator of the volume of products manufactured by this enterprise.

In general, they can be displayed as follows:

${ }^{10}$ Безус А.М., Безус П.І. Управління розвитком підприємства: моделі та методи : монографія. Київ : ВПЦ АМУ, 2008. 152 с. 
- the dependence of production on the number of personnel $-V=f_{l}(K)$;

- the dependence of production on the supply of raw materials $V=f_{2}(L)$;

- the dependence of production on the active part of fixed assets $V=f_{3}(M)$.

After defining these functions, we can formulate in the final form the necessary limitation for this model, which should provide a given increase in production volume $(\Delta V)$, in which case it can take the following form:

$$
\mathrm{f}_{1}(\mathrm{~K})+\mathrm{f}_{2}(\mathrm{~L})+\mathrm{f}_{3}(\mathrm{M}) \geq \Delta \mathrm{V}
$$

The next step is to determine the type of each of the functions that describe the nature of the changes occurring in a given production, and to determine the values of the buildup of selected factors at which a given increase in production will be achieved.

In addition to the limitations in the mathematical model, it is necessary to determine the objective function. Due to the fact that an economic and mathematical model is being created for the task of optimally increasing the production volume of an enterprise by increasing the volume of production factors, exactly this task is the basis for the formation of the objective function of the model. Given that increasing the indicator of each of the factors requires different unit costs for the production of additional products, it is necessary to compare all possible options for further changes in factors to select the optimal development option for this enterprise. In this regard, it is necessary to determine such a combination of selected factors and the buildup of each of them that, with an increase in production by a given amount, will lead to minimum total costs of the enterprise, and will be the optimal solution to this problem. Thus, the objective function reflects the goal of reducing production costs while increasing the volume of all influential factors of production. But before formulating the objective function, it is necessary to determine the dependence of production costs on the buildup of each factor. To do this, it is necessary to determine the function of cost changes from increasing its volume that is suitable for each factor. So, the change in costs from increasing the number of industrial production personnel $(\Delta K)$ reflects the function $U=u_{1}(K)$; the function $U=u_{2}(L)$ reflects the production costs from increasing the total volumes of raw materials $(\Delta L)$; the function $U=u_{3}(M)$ reflects production costs from building up the active part of fixed assets $(\triangle M)$. 
The objective function of the formulated problem model reflects the main goal - the optimal increase in the enterprise's production by increasing factors and is expressed through minimizing the total costs, which can be represented in the following form:

$$
\mathrm{u}_{1}(\mathrm{~K})+\mathrm{u}_{2}(\mathrm{~L})+\mathrm{u}_{3}(\mathrm{M}) \rightarrow \min .
$$

In general, the task of optimally increasing production volumes due to production factors is to find such unknown values of increasing the factors identified during the analysis that will provide a given level of increasing the volume of production, while the restrictions for each factor will be met, and the total cost of increasing these factors will be minimal ${ }^{11}$.The general view that the mathematical model of this problem acquires is as follows:

Target function:

$$
\mathrm{u}_{1}(\mathrm{~K})+\mathrm{u}_{2}(\mathrm{~L})+\mathrm{u}_{3}(\mathrm{M}) \rightarrow \min
$$

Limitation:

$$
\begin{gathered}
\mathrm{f}_{1}(\mathrm{~K})+\mathrm{f}_{2}(\mathrm{~L})+\mathrm{f}_{3}(\mathrm{M}) \geq \Delta \mathrm{V} \\
0 \leq K \leq a \\
0 \leq L \leq b ; \\
0 \leq M \leq c, \\
a \geq 0, b \geq 0, c \geq 0,
\end{gathered}
$$

where $\Delta V$ - increase in production volume;

$a, b, c$ - limit values of the buildup of each factor, in accordance with the capabilities of the enterprise.

After determining the boundaries of the growth of factors, it is necessary to determine the influence of the growth of the values of each of the factors on the subsequent increase in production volumes. To determine the described dependencies, it is advisable to use simulation.

To reproduce the predicted values for each of the dependencies, time series are constructed. To determine the parameters of time series in the form of input information, empirical data are introduced that characterize the current production and reflect the patterns of changes and random fluctuations of each factor.

\footnotetext{
${ }^{11}$ Безус П.І. Моделювання процесу економічного розвитку виробничого підприємства : автореф. дис. на здобуття наук. ступеня канд. екон. наук : спец. 08.00.11 «Математичні методи, моделі та інформаційні технології в економіці». Київ, 19 с.
} 
In the case of construction, the time series should reproduce the value of potential production volumes, which will be due to adjustments in the process of increasing the volume of a certain factor. To build the dependence of production volume on the factor buildup, it is necessary to note all the equal empirical time series for each of the factors and determine the indicators of possible output volumes for each factor. The obtained functions for each production factor $\left(V_{i t}=f_{i}(t)\right)$ provide an opportunity to establish the dependence of changes in production volumes on increasing volumes of the studied factors. But the dependence of increasing production volumes on an increase in any factor can acquire intensive growth only at the initial stage of increasing the volume of this factor. At the next stages, there will be a decrease in the proportional increase in production volumes with the same increase in the amount of this factor. This is due to the fact that at the next stages, an increase in the volume of the analyzed factor begins to negatively affect the growth in the volume of production of the deterrent effect of other factors. Thus, the dependencies that are determined are approximated by a staircase dependence $^{12}$. To determine the parameters of the staircase dependence, the least squares method is used, but the linearization of the curve is also used. After determining the parameters of the time series of the dependencies of indicators of potential production volumes for each of the production factors, an economic-mathematical model is created. Due to the fact that the established dependences of changes in production volumes on the buildup of each factor, taking into account their mutual influence, are presented in the form of nonlinear functions, the constructed model belongs to the class of nonlinear programming problems of a separable form and in this case does not have an exact solution method. For practical implementation, one of the known methods can be applied with the help of which this task will be transformed into a linear programming task ${ }^{13}$.

\section{CONCLUSIONS}

Ukraine's GDP growth is extremely low. One of the reasons is that manufacturers of gross domestic product are in a state of limited resources and that, in turn, limits their ability to increase production. Therefore,

\footnotetext{
${ }^{12}$ Швачич Г.Г. Сучасні інформаційні технології в математиці для економістів. Київ : ЦНЛ, 2003. $236 \mathrm{c}$.

${ }^{13}$ Кузнецов Ю.П., Кузубов В.И., Волощенко А.Б. Математическое программирование. Москва : Высшая школа, 1980. 224 с.
} 
under such a condition, methods of increasing production volumes by business entities without attracting investments deserve special attention due to the determination and optimal use of reserves for each production factor. The proposed model of optimal increase in production volumes allows us to provide a given level of increase in production volume with minimal costs for building up production factors defined in the process of analysis.

\section{SUMMARY}

The work explores a method of increasing production volumes due to production reserves. The total reserves of production are determined, for which the actual value of the indicator under study is correlated with its potential. The dependences of changes in production volumes on increasing volumes of each of the factors are determined taking into account their mutual influence. An economic-mathematical model of the optimal increase in production volumes is proposed.

\section{REFERENCES}

1. Статистичний щорічник України за 2016 рік. Державна служба статистики Украӥни. Київ : ТОВ «Август Трейд», 2017. $552 \mathrm{c}$.

2. Безус П.І. Моделювання нарощування обсягів виробництва. Економіка та підприємництво : Збірник наукових праць. 2007. Вип. 18. С. 307-312.

3. Скурихин В.И., Шифрин В.Б., Дубовский В.В. Математическое моделирование. Київ : Техніка, 1983. 270 с.

4. Безус П.І. Моделювання процесу економічного розвитку виробничого підприємства : автореф. дис. на здобуття наук. ступеня канд. екон. наук : спец. 08.00.11 «Математичні методи, моделі та інформаційні технології в економіці». Київ, 19 с.

5. Крамаренко B.I. Управління ресурсами підприємства. Київ : ЦНЛ, 2004. 288 с.

6. Антоненко Г.Я., Клименюк Н.Н., Калишук Д.А. Производственный потенциал предприятий сборного железобетона. Київ : Вища школа, 1982. 132 с.

7. Гавва В.Н. Потенціал підприємства: формування та оцінювання. Київ : ЦНЛ, 2004. 224 с. 
8. Безус А.М., Безус П.І. Управління розвитком підприємства: моделі та методи : монографія. Київ : ВПЦ АМУ, 2008. 152 с.

9. Швачич Г.Г. Сучасні інформаційні технології в математиці для економістів. Київ : ЦНЛ, 2003. 236 с.

10. Кузнецов Ю.П., Кузубов В.И., Волощенко А.Б. Математическое программирование. Москва : Высшая школа, 1980. 224 с.

\section{Information about the author:}

Bezus P. I.

$\mathrm{PhD}$ in Economics, Associate Professor, Associate Professor Department of Management and

International Economic Relations, V. I. Vernadsky Taurida National University 33, John McCain str., Kyiv, 02000, Ukraine 